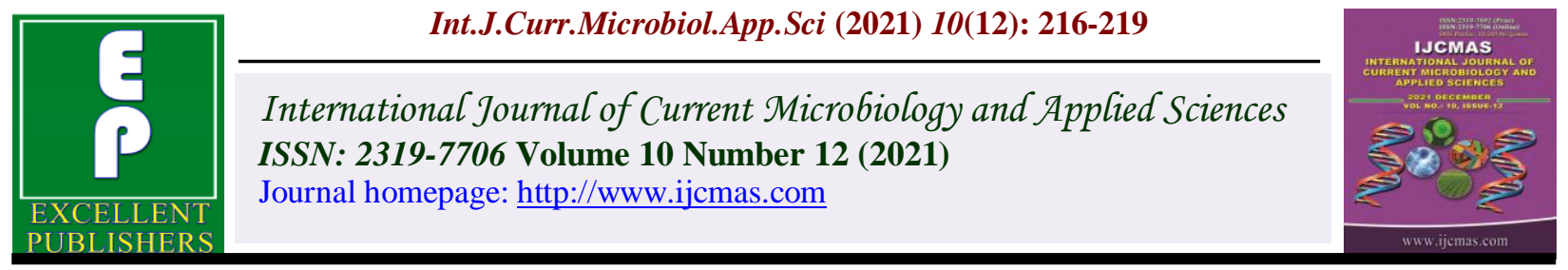

Original Research Article https://doi.org/10.20546/ijcmas.2021.1012.025

\title{
Environment and Living Condition of Zaskar Ladakh
}

\author{
Tashi Dolkar*, Sabiya Asmat, Feroz Din Sheikh, Shahnawaz Dar and Showket Dar
}

Krishi Vigyan Kendra, leh II Nyoma Sher-E-Kashmir University of Agriculture Science and Technology of Kashmir, Srinagar, Jammu and Kashmir, India

*Corresponding author

\section{A B S T R A C T}

\section{Keywords}

Zanskar, Livestock, Yak, Zho, Doksa, Sheep

Article Info

Received:

06 November 2021

Accepted:

30 November 2021

Available Online:

10 December 2021
The natural environment of Zanskar presents a very harsh and fragile system. The villages are mostly situated along the two main tributaries of Zanskar River. Zanskar range is the most important mountain range of Zanskar tehsil. There are varieties of domesticated animals which are used for different purposes in Zanskar. These domestic animals include ponies, asses, horses, sheep, goats, yaks, dogs, and fowls. Yak is another important animal of Zanskar, and is also known as the "ship of snow". The herders depends on highland pastoralism and kept temporary settlements locally called doksa. In doksa they reare yak, cow, zhomo, zho. The doksa produce around milk, butter, churphay (dried cottage cheese).

\section{Introduction}

Zanskar comes from the local word "Zangskar" meaning white copper. Zanskar is basically a Buddhist area with a small Muslim population. It covers area of some $7000 \mathrm{Km} 2$ and is situated at an elevation between 3500 and 7000 meters above the mean sea level. Its climate is very severe and it remains cut off from the rest of the world from November to June when only limited helicopter service is its only link with outside world. The region remains snow-covered during winters and movement of people comes to nearly standstill even within the region. Winter is severely cold and nearly no outdoor activity is possible for three to four months. People live in small houses build of stone, mud and wood. Human beings and domestic animals share the same cooking-cum-sleeping room on ground floor during winter months. Domestic animals are grazed on natural pastures in summers but have to be stall-fed during winters.

The climate of Zanskar valley is extremely dry and cold. Annual precipitation is only around $100 \mathrm{~mm} /$ year and humidity is very low. In this region, above 3,000 meters elevation, winters are extremely cold. The average January temperature of the valley is $-20{ }^{\circ} \mathrm{C}$ which drops as low as $-40{ }^{\circ} \mathrm{C}$. The vegetation of Zanskar mainly consists of alpine and 
tundra plant species, which are mainly confined on the upper slopes which receive more precipitation. Many species of Hippophae - the sea-buckthorns are found in the region with minimal soil humidity. The alpine meadows are covered with edelweiss (Leontopodium alpinum). Landuse by the local human population is mainly semipastoral agriculture based on livestock grazing and agriculture. Cultivated crops including barley, lentils, and potatoes which are grown by farmers at the lower elevations. At higher elevation livestock are major source of livelihood. Domesticated animals consists of yak, dzo, sheep, horse, and dog. The wildlife in Zanskar is represented by marmot, bear, wolf, snow leopard, kiang, bharal, alpine ibex, wild sheep and goats. (Chhering Tandup) In the mountainous region like Zanskar, agriculture is the mainstay of the people. $95 \%$ of the population are engaged in this activity through sedentary cultivation and pastoral animal rearing. Agricultural implements used by farmers are crude and primitive. Zho, a hybrid between yak and cow is deployed in drawing the small plough. The subsistent farming is still practised because of unfavourable climatic condition and highly fragile mountain ecosystem. The agriculture season sometimes gets delayed due to accumulation of snow in fields in great depths, particularly in lower altitudes (basin region) due to avalanching in spring season results in late sowing of seeds. To clear the snow from fields and to melt the snow, the farmers spread stored soil that enhances albedo by absorbing warmth from the sun. The region supports the cultivation of selected crops like wheat, Grim (barley) Pea, fodder and Vegetable that grow in a short period.

\section{Materials and Methods}

Zanskar, Zahar (locally) or Zanskar, is a tehsil of the Kargil district, which lies in the Indian union territory of Ladakh. The administrative centre is Padum (former Capital of Zanskar). Zanskar covers an area of some 7,000 square kilometres $(2,700 \mathrm{sq} \mathrm{mi})$, at an elevation of 3,500-7,135 metres (11,500-23,409 feet). Zanskar is among the cold arid inhabited highlands of the world. In zanskar valley, cropland is less than $2 \%$ of the geographic area.

Fig.1

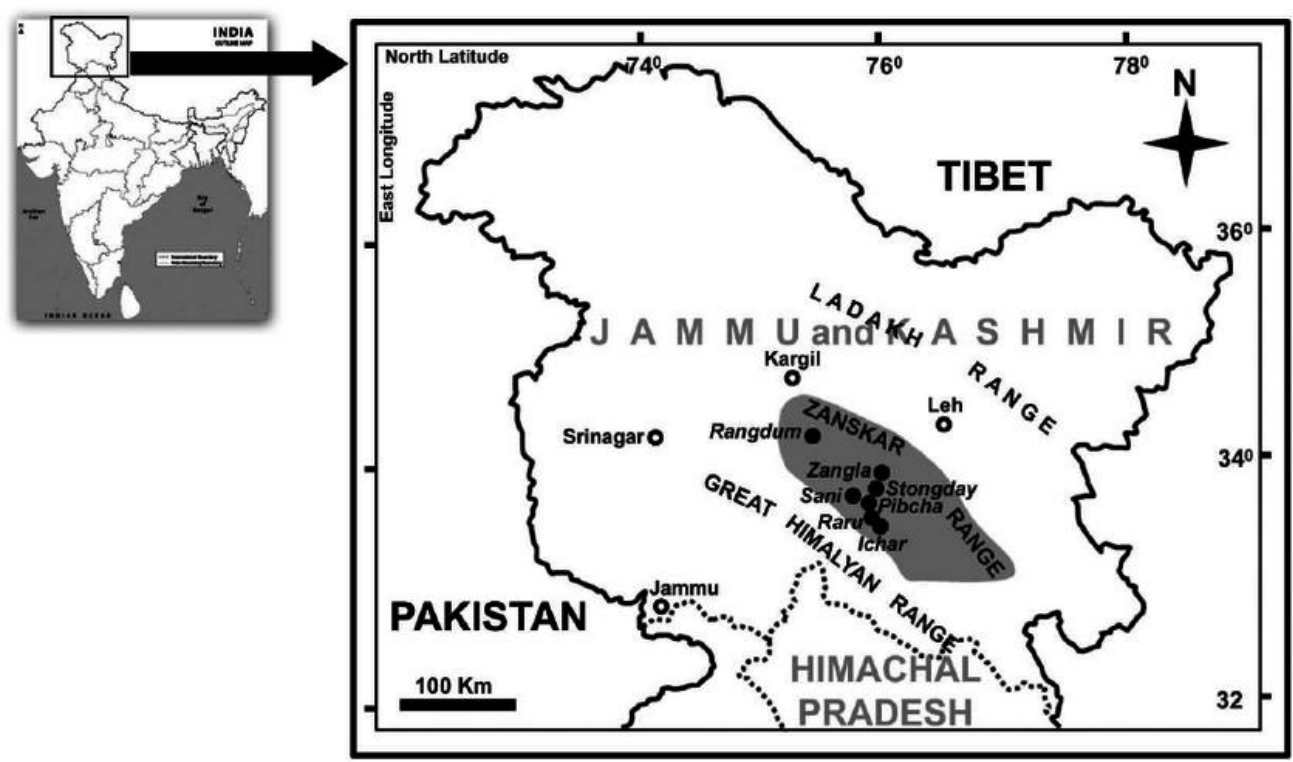




\section{Result and Discussion}

Total farm land holdings were about 1221.43 $\mathrm{km}$ sq cropped land were $100 \%$ irrigated, zanskar people totally depend upon farming and livestock husbandry were the major food and income sources and people were engaged year around. single cropping system in zanskar that is April to September, after that they were preparing to manage winter, gathering or collecting food, fuel, wood, cow dung and other resources and fodder to feed the livestock for long winters.

Table.1 Basic information of the zanskar valley

\begin{tabular}{|c|c|}
\hline Average land holding & $\mathbf{1 2 2 1 . 4 3} \mathbf{~ k m ~ s q}$ \\
\hline Population of the valley & 14450 \\
\hline Irrigation & $100 \%$ irrigation farming \\
\hline Cropping season & April - September \\
\hline
\end{tabular}

Table.2 Living Condition of Zanskar valley Respondents

House

\begin{tabular}{|c|c|}
\hline Kaccha(mud house) & $\mathbf{5 5 \%}$ \\
\hline Semi pucca & $\mathbf{3 0 \%}$ \\
\hline Pucca(cemented) & $\mathbf{1 5 \%}$ \\
\hline
\end{tabular}

Drinking water

\begin{tabular}{|c|c|}
\hline Pipe & $\mathbf{2 4 \%}$ \\
\hline Hand pump & $\mathbf{2 0 \%}$ \\
\hline Spring /Stream & $\mathbf{5 6 \%}$ \\
\hline
\end{tabular}

The above table show that $(55 \%)$ of the respondents had Kaccha House (Mud House) because of poverty and lack of heating facilities and unbearable cold in winter they had kaccha house, $30 \%$ had semipucca house and also had well wood constructed within the house because of cold climate, whereas $15 \%$ of the respondents had pucca that is cemented house.

\section{Doksa System in Zanskar}

Herders move with their Stock in first week of may to high pastures stayed there for three month in summer some of they returns to their villages at the time of crop harvest in ending
September and most of the doksa people come down during thrasher time. The study investigate that in Mid summer the herders depends on highland pastoralism and kept temporary settlements locally called doksa. In doksa they reare yak, cow, zhomo, zho. The doksa produce around milk, butter, churphay (dried cottage cheese). The climate of Zanskar valley is extremely dry and cold. single cropping system in zanskar that is April to September, Cultivated crops including barley, wheat and potatoes which are grown by farmers at the lower elevations. At higher elevation livestock are major source of livelihood. Domesticated animals mostly consist of yak, dzo, sheep, and cow. 


\section{References}

Anup raj, 2020 Livelihood Dependence on Highland Pastoralism (Doksa) In Trans-Himalayan Region of Zanskar, Ladakh, International Journal of Environment and Climate Change 10(12):67-76,issn:2231-4784

Chhering Tandup, 2014 International Journal of Scientific and Research Publications, Volume 4, Issue 8, ISSN
2250-3153 www.ijsrp.org Natural Environment of Cold Desert Region Zanskar (Ladakh) Https://En.M.Wikipedia.Org John crook henry osmaston,(1994) Himalaya Buddhist Villages, Environment, Resources, Society And Religious Life, In Zanskar, Ladakh, Motilal Banarridas Publishers Limited, New Delhi.

\section{How to cite this article:}

Tashi Dolkar, Sabiya Asmat, Feroz Din Sheikh, Shahnawaz Dar and Showket Dar. 2021. Environment and Living Condition of Zaskar Ladakh. Int.J.Curr.Microbiol.App.Sci. 10(12): 216-219. doi: https://doi.org/10.20546/ijcmas.2021.1012.025 